\title{
Triple Helix analysis from Fapemig data for the last 10 years
}

\section{Crystyane Ferreira Bernardino, Joseane Viola Debortoli,} Washington Gonçalo Rodrigues Veloso, Adriana Gontijo Nunes and Lilian Bambirra de Assis Centro Federal de Educação Tecnólogica de Minas Gerais, Belo Horizonte, Brazil

\begin{abstract}
Purpose - The puropose of this study is to analyze the functioning of the triple helix interaction in Minas Gerais, through the case study of the Minas Gerais State Research Support Foundation (Fapemig).

Design/methodology/approach - The information was collected from the Activity Reports published by Fapemig. Quantitative methods were used for structural analysis and data tabulation of the researched and qualitative programs for a procedural and documentary analysis of projects promoted by Fapemig between the years 2009 and 2018.

Findings - The Fapemig showed itself to be a fundamental agent for innovation and the development of interactions between the state, universities and companies in Minas Gerais, through the creation of programs, offered in public notices, financing them and creating a space of consensus among the agents.

Originality/value - There is few research on triple helix interaction for the state of Minas Gerais; most research on this topic is concentrated in some regions of the country, and the present work contributes to fill this research gap, besides demonstrating, in a case study, applications of recent and still little-explored concepts of the literature on triple helix.
\end{abstract}

Keywords Triple helix, Fapemig, Minas Gerais

Paper type Case study

\section{Introduction}

Innovation is a key challenge for the development of companies, countries and society in general. Locally, it happens through the Regional Innovation Systems (RIS), a set of networks between public and private agents that interact in each territory, with its own infrastructure, generating knowledge and expanding innovations (Buesa, Heijs, Pellitero, \& Baumert, 2006). These agents are involved in interactive learning (Cooke, 2005) where the knowledge produced is disseminated among organizations, such as universities, research and development (R\&D) institutes and technology transfer agencies, among others (Doloreux \& Parto, 2005).

The innovative process involves multiple actors, developing from the interactions between them (Edquist, 2010). In addition, it is a systematic process that needs to be

(C) Crystyane Ferreira Bernardino, Joseane Viola Debortoli, Washington Gonçalo Rodrigues Veloso, Adriana Gontijo Nunes and Lilian Bambirra de Assis. Published in Innovation \& Management Review. Published by Emerald Publishing Limited. This article is published under the Creative Commons Attribution (CC BY 4.0) licence. Anyone may reproduce, distribute, translate and create derivative works of this article (for both commercial \& non-commercial purposes), subject to full attribution to the original publication and authors. The full terms of this licence may be seen at http:// creativecommons.org/licences/by/4.0/legalcode

Coordenação de Aperfeiçoamento de Pessoal de Nível Superior.

Código de Financiamento 001.

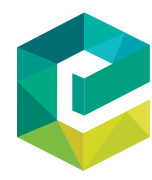


INMR

17,4

institutionalized both by organizations and by regions, sectors and countries. Universitybusiness interaction has the potential to be one of the engines for building this development, and therefore must be a key part of a given RIS. The triple helix, on the other hand, brings yet another element to this construction, including governments as a source of promotion to make university-company interaction even more fruitful (Etzkowitz \& Zhou, 2017).

The Brazilian scientific development policy took place from 1951 onwards, with the Foundation of the National Council for Scientific and Technological Development (CNPq), called until 1974 National Research Council. This policy was fostered by the Military Regime, which supported the top-to-down innovation system (Etzkowitz, Mello, \& Almeida, 2005). Since the fall of the Military Regime, innovation policy in Brazil has increasingly turned to the bottom-up and decentralized model, in which universities, federal technology centers, municipalities and states. Although companies work co-laterally, the Federal Government remains the driver of these policies, keeping the top-to-down model active (Almeida, 2004).

Thus, the Research Support Foundations (FAPEs), which are the state spheres of action of the Brazilian Innovation Policy, because of their intrinsic characteristics, may represent one of the main sources of stimulus and fostering the interaction of academia with companies. In Minas Gerais, this role is played by Fapemig - Research Support Foundation of the State of Minas Gerais, through agreements, scholarships and other initiatives.

In this sense, this research aims to shed light on the functioning of the triple helix interaction, through the case study of the performance of the Fapemig as an inducer of this relationship in the state. The objective of our research is to investigate the occurrence of the triple helix interaction in the state of Minas Gerais and survey the results of this interaction through the database of projects promoted by Fapemig between the years 2009 and 2018.

Research related to the triple helix, currently in Brazil, comes from research groups concentrated in the states of Rio de Janeiro (UFF, UFRJ and PUC-RJ), São Paulo (USP and UNICAMP) and Curitiba (UFPR) (Amaral \& Messias, 2018). The potential of this type of interaction is known to promote knowledge-based economic and social development, as can be seen in several emerging international scenarios, as well as in policies and programs in Europe, Asia and Latin America (Etzkowitz \& Zhou, 2017; Todeva, Alshamsi, \& Solomon, 2019), so it is necessary to expand these researches to other regions of Brazil, because few studies are found investigating the triple helix model in the state of Minas Gerais (Sobrinho \& Gonçalves, 2011; Carvalho \& Coronel, 2012; Pereira, Marques, Garcia, \& Gava, 2015; Rodrigues \& Gava, 2016), contributing to literature on the subject. Besides, we aim at demonstrating herein, through a case study, some applications of recent and still littleexplored concepts by literature on triple helix.

In addition to this introduction, the work has a theoretical reference section, which addresses the concepts of triple helix interaction, the National Innovation System (NIS) and the RIS, with a brief characterization of the RIS of Minas Gerais, exposing its particularities and potentialities to elucidate the context in which the triple helix interaction occurs in the state. Section 3 deals with the methodology used in the elaboration of the research. Section 4 presents the analysis of the data, and the Section 5 the discussion of these results and the conclusions of this research.

\section{Theoretical framework}

Three institutions play a crucial role in the development of the innovation process: universities, companies and government. The partnership between these three institutions is conceptualized as triple helix, a universal model of innovation (Leydesdorff \& Etzkowitz, 1998) and the secret behind the development of Silicon Valley. At triple helix, these three 
institutions are considered spheres of primary institutions, interacting with the objective of promoting development through sustainable innovation and entrepreneurship, and the interaction between them can give rise to new secondary institutions, hybrid organizations and the reformulation of the roles of each helix (Etzkowitz \& Zhou, 2017).

According to Leydesdorff and Etzkowitz (1998), each agent can progressively assume roles of other propellers. Universities will have to abandon the posture of ivory towers, ceasing to produce for themselves and adopting a more entrepreneurial and applied behavior, in terms of return to society; intellectual property and technology management gain emphasis; as well as patent marketing and the creation of technology-based companies at universities through incubation processes. On the other hand, companies must increasingly contribute to the production of knowledge, as they are closer to the demands of consumers, indicating new paths for technological development (Leydesdorff \& Etzkowitz, 1998). The government will provide the infrastructure and lines of financing for the creation of companies, especially for those resulting from research financed by it, as well as the implementation of actions and laws as fundamental mechanisms for the cooperation process (Alvim, 2019).

Over the years, this concept has been evolving, motivated by incremental ideas added to the model. In addition, the interaction between institutional spheres is also constantly changing, with new forms of representation. These evolutions in the concept included society (Quadruple Helix) and the environment (Quintuple Helix) as important propellers in the innovation dynamics (Carayannis \& Rakhmatullin, 2014).

Despite the rise of studies on the new theoretical approaches to propellers, some authors report difficulties to work with them (Yoon, Yang, \& Park, 2017) and, in this research, we opted for the concept of triple helix, which is more consolidated and because we believe that the difficulties in integrating these spheres are already many; we limit, therefore, our study to the interaction only of university-company-government. The occurrence of this interaction has been verified through the approximation of Brazilian research groups with companies (Rapini, 2007; Coutinho, 2018). It has also gained prominence in academia, with publications on the subject increasing considerably from 2010 (Rizzi, Mazzioni, Poli, \& Moura, 2018).

Until the triple helix model is fully operational, two other intermediate models can be observed (Figure 1). In the statist model, the state directs the entire process of development of industries based on new technologies. The production structure and the educational and research institutions are subordinate pieces to the government. Innovation takes on a normative character, the result of government guidelines and not of relations between universities and industry (Leydesdorff \& Etzkowitz, 1998; Etzkowitz, 2009).

In the laissez-faire model, the government's influence diminishes, limiting its role to that of regulation and purchase of products (Etzkowitz, 2009). But the spheres turn to each other

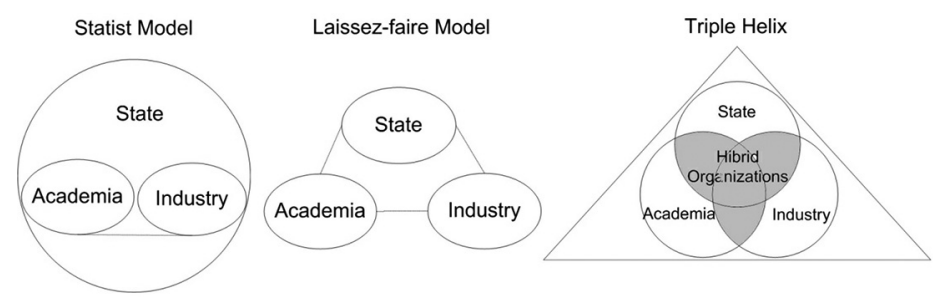

Source: Adapted from Etzkowitz \& Zhou (2017)

Figure 1. Representation of the stages of development of the triple helix 
INMR

17,4

only when necessary (Arantes \& Serpa, 2012) in a very incipient interaction, with still very strict limits (Etzkowitz \& Zhou, 2017).

The informal exchange of information and the provision of specialized services, such as consultancy, training and specialization courses, often initiate projects between universities, government and companies. Based on the perception of common interests and the establishment of a relationship of trust, new stages of cooperation are advanced, such as technology transfer, exchange of researchers and development of joint projects and research (Etzkowitz, 2013). For companies, this closer relationship brings the benefits of acquiring intellectual capital, mitigating uncertainties and learning in the innovation process (Moura, Silva, \& Fischmann, 2012).

To provide more dynamism and enhance integration among the actors, the government can act in what is called the consensus space (Ranga \& Etzkowitz, 2015) because of its regulatory control function (Leydesdorff \& Meyer, 2006). This action requires legitimacy, decision-making power and relational capacity from the government toward the other helix to conduct a process of discussion of strategies to promote innovation (Cingolani, 2013) in a collaborative process simultaneously top-down and bottom-up.

The entrepreneurial state spreads innovation across sectors of the economy, mobilizing networks of actors, institutions and organizations that already exist and creating new networks and serving as a risk investor (Mazzucato, 2015). The consensus space can be an organization or individual with the capacity to bring together the relevant actors of the local, state or national innovation ecosystem for discussions, debates and analyzes in favor of the execution of the innovation policy (Ranga \& Etzkowitz, 2015), taking into account weaknesses and regional vocations to use innovation as a strategy to promote regional development.

Triple helix's three institutions also make up a larger system, the NIS, which can be defined as a network of economic agents and socio-cultural and political institutions that drive innovative performance (Mytelka, 2016). Such a system promotes the development and diffusion of innovations, a process undertaken collectively by researchers, managers, funding agencies, consumers and political decision-makers (Mazzucato, 2015). Thus, innovation is understood as an interactive process, in which companies, institutions, R\&D, innovation centers, organizations, universities and banks interact with each other, supporting and exercising their roles in the creation of new products, processes and forms of organization (Mytelka, 2016). Innovation, previously limited to the development of new products, creates organizational arrangements that promote the innovative process, new configurations of institutional spheres.

The NIS approach contributes to the analysis of the determinants of technological progress and innovation, especially by allowing a broad assessment of the role of the different institutions that make up the system, as well as the information flows and interactions between them. Based on the concepts of the NIS theory, and aspects related to the regional economy, the RIS approach was developed in the early 1990s, emphasizing the importance of regional resources and potential for technological and economic development of local economy (Cooke, 2005).

According to Doloreux and Parto (2005), innovation is spatially localized, as it occurs in a well-defined historical, institutional, political, social and economic context, with local rules, conventions and norms. For the regional development of innovations to occur, it is necessary to create an environment that stimulates learning, technical qualification, diffusion and incorporation of new technologies, as well as the relationship between the spheres of basic and applied research, between researchers and entrepreneurs. 
The Minas Gerais RIS, specifically, reflects the Brazilian NIS, based on the import substitution process and therefore is immature. Sousa Júnior (2014) draws attention to the fact that, in Minas Gerais, most of the infrastructure for generating scientific and technical knowledge comes from the state.

Like the national one, RIS-MG is biased toward public institutions over private R\&D institutions, with product development being restricted, where a small number of large firms have specific R\&D departments (Sousa Júnior, 2014). Universities and federal research institutions play a central role in this system. Minas Gerais is the state with the largest number of federal universities in the country; the state houses 22 higher education institutions, including Federal Institutes of Technology and Federal Universities (IBGE, 2019).

Even with the strong presence of so many higher education and research institutions, some authors point to the presence of deficiencies in the state system, such as the coexistence of a modern sphere with a marginalized one, the low involvement of industries in activities related to innovation and regional concentration of scientific and technological productions (Albuquerque, 1999; Salles, Rocha, Porto, \& Vasconcelos, 2017). Therefore, the correction of these regional inequalities is essential for the state's economic advance.

The RIS-MG has scientific institutions of national relevance, linked to the state's economic vocations, such as the Minas Gerais Agricultural Research Corporation (EPAMIG) and the Ezequiel Dias Foundation (FUNED). As support for financing, there are strong institutions, such as the Development Bank of Minas Gerais (BDMG) and Fapemig, object of this study. These institutions, among many others, contribute to the scientific development and economic activities of the state (Wylinka \& Nesta, 2019).

The "Innovation Law of Minas Gerais" is also an advance, in force since 2008. This law supports the participation of scientific and technological institutions in the innovation process, the encouragement of independent researchers and inventors, the support of the State Science and Technology Institutions (ICTMGs) and private institutions, technology parks, technology-based business incubators and also the encouragement of business innovation. It makes the necessary adaptation of federal law to the state level by creating "regional mechanisms" for its execution. It safeguards the possibility of sharing ICTMG laboratories, equipment, instruments, materials and other facilities with small and microenterprises and establishes the conditions for the commercialization of inventions and technologies by public research institutions (Lopes \& Barbosa, 2008). RIS-MG has the potential to grow, and mechanisms for its strengthening are being developed.

With the clear concepts and historical contextualization of the structure for innovation in the state of Minas Gerais, it is assumed that the characteristic interaction of the triple helix is recent, and occurred incipiently throughout the analyzed period, because the RIS-MG is strengthening and the legal and institutional apparatus for more robust interactions is a few years before the observed period. The following shows the methodological procedures to achieve the objectives of this research.

\section{Methodological procedures}

This section presents the methodological procedures used to analyze the functioning of the triple helix interaction in Minas Gerais, through the case study of the Minas Gerais State Research Support Foundation (Fapemig).

For the selection of the information treated in our study, we carried out a survey in all activity reports published by Fapemig from 2009 to 2018. This time horizon was chosen because, before this time, there is only one compiled management report, covering the activities from 2004 to 2014. Therefore, to follow the defined pattern, we opted for the 
INMR

17,4

reports whose information is available, are similar and comprehensive, from 2009 to 2018. Because the data were collected in different points in time, a longitudinal survey is presented, covering a horizon of ten years.

Given the nature of the problem, we opted for both qualitative and quantitative approaches, with the integrated application of both research methods to enable a greater understanding of the topic addressed. In scientific research, quantitative and qualitative treatment of results can be complementary, enriching the analysis and final discussions. While social scientists work on statistics capturing the visible, ecological, morphological and concrete region, the qualitative approach deepens into the world of the meanings of human actions and relationships, an unnoticeable and non-captive side in equations, averages and statistics (Minayo, 1994).

In this perspective, for quantitative analysis, we used Windows $₫$ Excel $365 \AA$ and IBM $₫$ Statistical Package for Social Science (SPSS)®, version 22. The method chosen was the descriptive statistical analysis using the crosstab table, because the dependent variable was qualitative and dichotomous. The first step was the tabulation of the data of the researched programs. The qualitative analysis was made for a procedural and documentary analysis of the projects promoted by Fapemig between the years 2009 and 2018. For this analysis, no software was used.

The technical procedure adopted was the case study. Godoi, Bandeira-de-Melo, and Silva (2010) state that the case study has been widely used in organizational studies. In this research, the case study was developed using, as the means of investigation, the documentary analysis of secondary evidence, whose main sources were reports from institutions linked to federal and state governments available on the Fapemig website, Transparency Portal and Ministry of Science, Technology, Innovations and Communications. Thus, the analysis of the documents allowed the reading of the particularities of the studied organization and the definition of the results. To manage data processing, dynamic spreadsheets were used in Excel.

As for the proposed objectives, a descriptive research was adopted, discussing the projects and phenomena found in the Fapemig reports analyzed, and describing the establishment of triple helix relationships.

Categories of analysis of the researched content were defined evaluating the occurrence or not of the triple helix. Content analysis is defined by Bardin (2011) as a set of constantly improving methodological tools that apply to extremely diverse content and continents. Therefore, the research was conducted from analysis categories that include the following programs developed by Fapemig:

- operational performance;

- special programs and projects;

- structuring, technological and innovation programs;

- intellectual property; and

- scientific dissemination.

Although the starting point was the above categories, the results will be discussed in the next section together, as the categories are fully related to each other.

\section{Results}

Research support foundations are regional in character and act independently. In Minas Gerais, the Foundation for Research Support of Minas Gerais (Fapemig) was created, based on the Delegated Law No. 10 of August 28, 1985 (Fapemig, 2019). It is the only agency to 
promote the development of institutions and individual research in the state and is linked to the Secretariat of Economic Development, Science, Technology and Higher Education of Minas Gerais (Sedectes). Fapemig aims to be recognized as the main agent driving scientific, technological and innovation development in the state of Minas Gerais. To this end, it aligns its mission and vision with the proposal of the triple helix, acting as a connecting agent between the knowledge produced in the academy and the proposal of creating a quality entrepreneurship and innovation within the state (Fapemig, 2019).

Fapemig encourages scientific and technological development through programs developed year by year with support modalities, such as financing research projects, granting scholarships, organizing and participating in scientific events, encouraging the formation of research networks and supporting scientific and technological publications. There are four lines of funding at Fapemig: Research, HR training, Technological innovation and Scientific divulgation. The promotion line "Technological innovation" encompasses all modalities that aim to encourage dialogue between academia and industry, being the main focus of this research.

Considering the data presented in Fapemig's annual reports from 2009 to 2018, an average of 25 programs per year can be observed, where thousands of projects are distributed. The programs are divided into five main areas, as follows:

(1) operational performance;

(2) special programs and projects;

(3) structuring, technological and innovation programs;

(4) intellectual property; and

(5) scientific dissemination.

Looking at Fapemig's programs in general, it was noted that most programs are partnerships between Fapemig and other government agencies and universities, research support programs, scholarships, teacher training, NIT support programs or government technology development and training programs. The interactions that characterize triple helix, between governments, universities and businesses, represent a share of approximately one-third of programs.

Of the total number of programs carried out between 2009 and 2018, 33.7\% involve triple helix, including support for research in companies, poles of excellence and innovation, articulation with the business sector, support for companies in technology parks and operationalization of the Minas Gerais Innovation System. Starting in 2016, after the rupture of the Mariana dam at the end of 2015, two new programs involving triple helix were entered: Recuperação da Bacia do Rio Doce and Nova Mineração. Figure 2 shows a comparison between the total number of programs carried out and those involving the triple helix.

In the axis of Structuring Technological and Innovation Programs, the main actions of triple helix are carried out, developed in strategic and multidisciplinary areas. A highlight is the Minas Gerais Innovation System (SIMI), established in December 2006 and active to date. The program's objective is to promote the convergence of governmental, business, academic research and technology actions to cooperatively develop innovation in the state. The SIMI portal is a strategic tool with important information on entrepreneurship, science, technology and innovation. It gathers in one place news about events, e-books, articles, job offers and notices, support material for entrepreneurial education, information on intellectual property and the DELA network (Women's Academic Legacy Entrepreneurship Challenge), among others. 
INMR

17,4

438

Figure 2.

Comparison of accomplished programs vs triple helix programs
COMPARISON OF THE ROGRAMS PERFORMED

2009 TO 2018

Total Projects $\square$ Triple Helix Projects

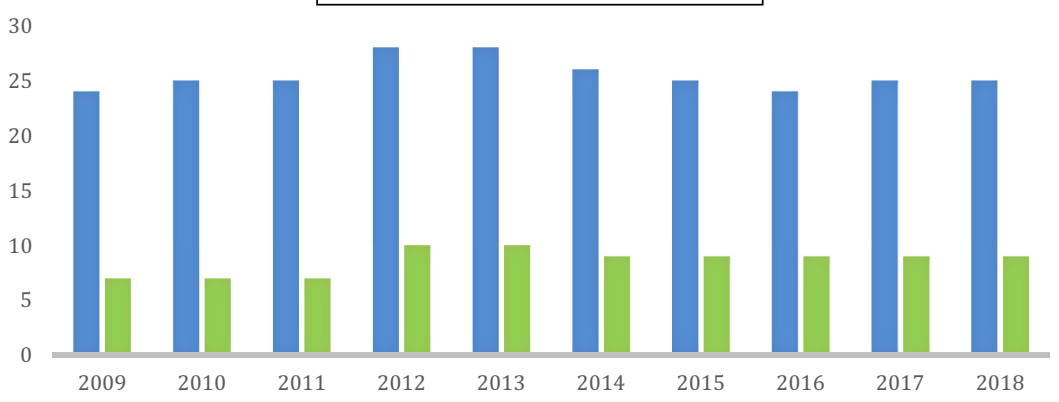

Source: Research data

Another highlight of the program is the innovation map, which allocates all structures related to innovation in the state, showing their information and geographic location, dividing them into categories: accelerators, R\&D centers, startup communities, financing agencies, incubators, associations, investors, open laboratories, technological innovation centers (NITs), business R\&D laboratories, technology parks, startups, universities and others. It provides greater visibility, access and articulation among the almost 400 actors in the innovation ecosystem of Minas Gerais, in addition to demonstrating its importance and magnitude. The methodology adopted with the principles established in the triple helix theory can be seen in Figure 3 .

The Pro-Innovation Program also deserves mention, a partnership established between Fapemig and BDMG, which aims to support innovation projects in technology-based companies located in the state. Its peculiarity, compared to traditional financing, is the flexibility in the concession and the flexibility of the guarantee guaranteed with the endorsement of the partners. Pro-Innovation includes fixed, intangible investments and working capital directly related to activities aimed at radical or incremental innovations that result in significant quality improvement, pioneering spirit or increased market competitiveness and greater productivity.

In this program, civil works, construction and renovations, new, used or imported machinery and equipment can be financed: installations, assemblies, furniture and utensils; utility vehicles and new trucks; computerization and technological development; R\&D; intangible investments and associated working capital. In 2017, thirty four financing proposals were submitted, of which twenty were approved, which totaled more than US $\$ 19 \mathrm{~m}$. With regard to the size of the companies claiming the pro-innovation line, $36 \%$ of the demand received in 2017 are from small companies, 28\% from micro and 24\% from medium-sized companies.

Throughout the year, Fapemig launches several calls for funding for scientific, technological and innovation research. In the surveyed data horizon, it is noted that the years 2009 and 2010 were that presented the highest offer of public notices, being that the largest number of notices launched per year was 25. In the years 2015-2017, 11 calls for bids/year were launched, and in 2018, 10 calls for bids, the lowest number in the surveyed period. The themes of the public notices are defined according to the guidelines provided by the State Council for Science and Technology - Conecit, the State Secretariat for Economic 


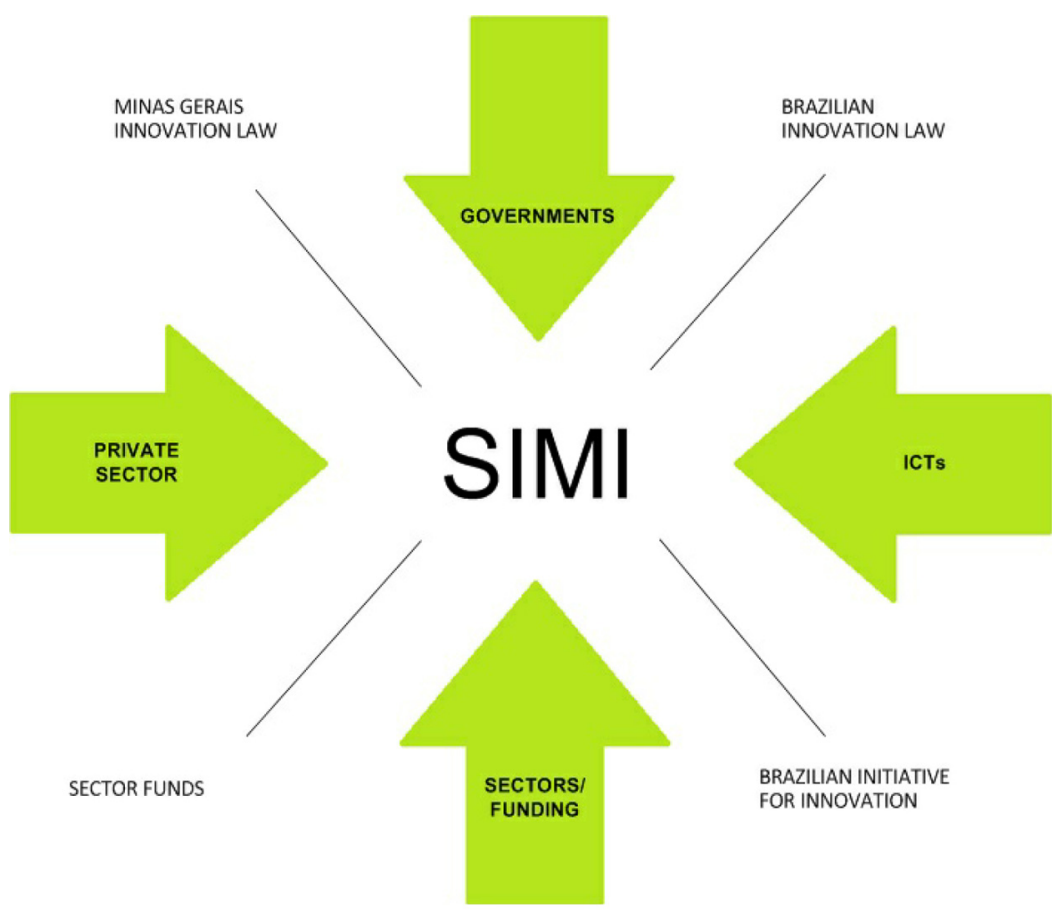

Source: Fapemig Activity Report (2009)
Analysis from Fapemig data

Figure 3.

SIMI methodology

Development, Science, Technology and Higher Education of Minas Gerais, Sedectes and its Board of Trustees. Figure 4 shows the list of the number of calls for bid launched by Fapemig per year.

Brazil does not have a strong tradition in the dynamics of exchanges between academia and the productive sector (Mazzucato, 2015), making this task of the FAPEs even more complex
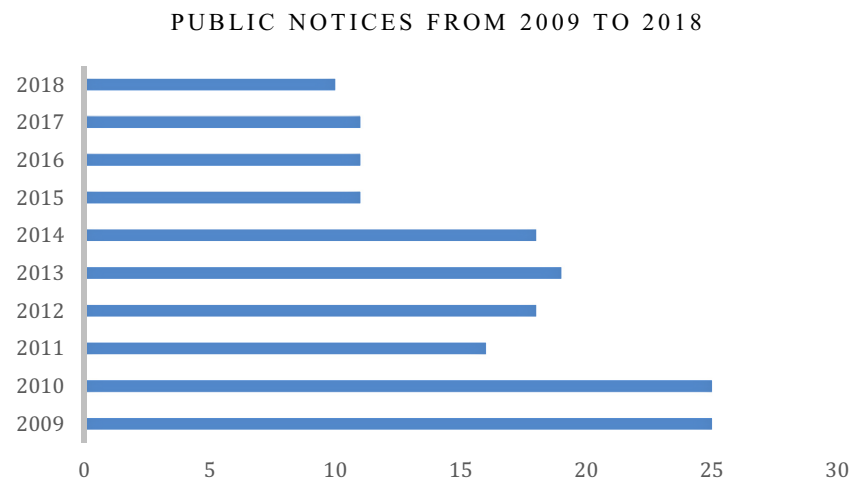

Source: Research data

Figure 4. Public notices by Fapemig in the period from 2009 to 2018 
INMR

17,4

440

Descriptive analyses
Table 1.

and important. But over the years analyzed in this research, it was noted that several companies, from small to large, were involved in Fapemig's programs, and companies from different sectors, such as automobile manufacturers, large appliance companies, development banks, mining and energy, steel, telecommunications equipment, power generation and transmission and information technology, among others. In its reports, Fapemig itself highlights some of these companies, which are mentioned in Table 1 and Figure 5.

Of the 18 companies participating in the FAPEMIG programs, the minimum number of participations is one year and the maximum number of years is six; the average participation is only 2.19 years, as shown in Table 2 . Vale was the longest partner of FAPEMIG programs for six years, and in the second position was observed Whirpool and Cemig for five years. Most companies used to partner with FAPEMIG in just one year. The key sectors of these companies featured in partner reports over the past 10 years have been mining, energy, automotive, communications and technology.

To be always aligned with the most innovative in Brazil and worldwide, Fapemig has established several international partnerships. Over the years analyzed in this study, partnerships were established with several countries: France, Germany, Australia, the United Kingdom, Canada and the USA stand out in this scenario. Their participation volumes are illustrated below, as well as the distribution of this participation over the years surveyed (Figure 7).

These partnerships are expected to strengthen and multiply, because in 2017, with the new statute of the foundation, the International Advisory was reformulated and became the Department of International Partnerships for Science, Technology and Innovation, subordinated to the Management of Innovation. Its competencies involve the execution, monitoring and organization of procedures and activities related to international contacts and partnerships, to build a solid international action strategy, aligned with the needs of the State of Minas Gerais.

\begin{tabular}{lccccr}
\hline & $N$ & Min & Max & Mean & SD \\
\hline EMP_PART_TT & 18 & 1 & 6 & 2.19 & 1.750 \\
Value list & 18 & & & & \\
Source: Data research & & & & & \\
\hline
\end{tabular}

Figure 5.

Brazilian companies involved in FAPEMIG programs from 2009 to 2018
PARTICIPATING COMPANIES

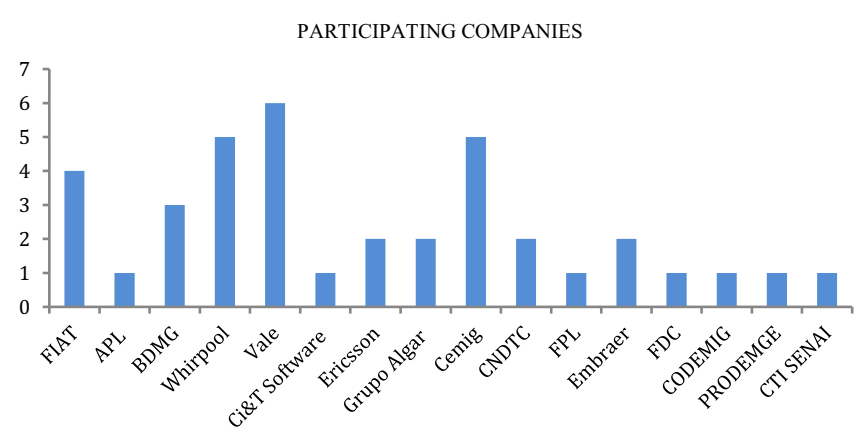

Source: Research data 
In the next topic, the main results of this research and their relationship with the literature are discussed; the final contributions and considerations are presented, in addition to suggestions for future work.

\section{Discussion and conclusion}

In a given RIS, there is always dependence and exchange relations with the NIS (Mytelka, 2016), relations that are clear when comparing the data in Figure 4 (number of notices) with the consolidated data of expenditures on Science and Technology (S\&T) of the Ministry of Science, Technology, Innovations and Communication, made available from 2000 to 2016 (Figure 8), including R\&D and Related Scientific and Technical Activities, as well such as the budget data foreseen for Fapemig (Table 2), extracted from the Transparency Portal of the Government of the State of Minas Gerais, where it is possible to infer the decline of expenditures on S\&T as a trend starting in 2016.

Fluctuations in expenses and budgets appear to be directly related to the number of proposals issued. Another relevant information inferred is that business and public investment work with a similar behavior, but there is a clear history in the Brazilian reality of the prevalence of public spending compared to private spending, when it comes to S\&T, as also demonstrated by Albuquerque in 1999, Mazzucato in 2015, Salles in 2018 and Alvim in 2019, which reinforces the need for government action for the operation of the triple helix.

State action indicates, not in the sense of control as in the statist model (Leydesdorff \& Etzkowitz, 1998), a model that is already unsustainable because of the dynamism necessary for the development of innovation (Edquist, 2010), but rather as an agent in the creation of space of consensus (Ranga \& Etzkowitz, 2015).

Fapemig, together with other institutions, such as the Minas Gerais Secretariat for Economic Development, Science, Technology and Higher Education and BDMG, among others, acted as the main source of financing and for the implementation of mechanisms that facilitate these interactions, such as the Minas Gerais Innovation Law. These actions corroborated with the role traced by the state in the literature of the triple helix (Cingolani, 2013; Todeva et al., 2019) and the entrepreneurial posture of the state (Mazzucato, 2015).

But Fapemig, in addition to these functions, also shows itself as the agent of the consensus space, in addition to providing risk capital, seeking to integrate the various agents of the RIS of Minas Gerais, in actions directed to this purpose, such as the SIMI and the Mining Map of

\begin{tabular}{ccrcr}
\hline Year & Budget & IPCA & Budget updated by IPCA & Variation \\
\hline 2014 & $1,767,931,816,00$ & $6.41 \%$ & $2.299,407,478,53$ & \\
2015 & $1,963,714,975,01$ & $10.67 \%$ & $2,428,219,970,06$ & $5.60 \%$ \\
2016 & $1,909,355,430,00$ & $6.29 \%$ & $2,157,206,949,01$ & $-11.16 \%$ \\
2017 & $1,673,094,526,97$ & $2.95 \%$ & $1,785,071,397,47$ & $-17.25 \%$ \\
2018 & $1,424,114,349,96$ & $3.75 \%$ & $1,477,454,552,94$ & $-17.23 \%$ \\
2019 & $1,228,359,68400$ & & $1,228,359,684,00$ & $-16.86 \%$
\end{tabular}

Notes: ${ }^{\text {IIPCA }}$ is the Broad National Consumer Price Index. IPCA aims to measure the inflation of a set of products and services sold at retail, referring to the personal consumption of families. It is the inflation reference index in Brazil. bIBGE - The Brazilian Institute of Geography and Statistics - is the main Brazilian data and information provider. This information aims to serve the public and private sectors, especially the federated entities and the union

Source: Prepared by the authors, based on data from the Minas Gerais State Transparency Portal
Analysis from

Fapemig data

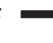


INMR

17,4

\section{2}

Figure 6.

Volume of international partnerships in FAPEMIG programs from 2009 to 2018
Innovation, programs that seek to articulate these agents and give visibility to all of them so that they know each other, work together and with systemic thinking.

As for companies, there was a progressive involvement in the programs, some of which were more frequent and, therefore, apparently institutionalized in the organization, and others became sporadically involved. It is interesting to note in Fapemig's programs the participation of large companies, as shown in Figure 6, as well as small and medium-sized companies, involved in the Pro-Innovation Program.

It is noteworthy that most of the companies mentioned in Fapemig's Reports and represented in Figure 6 are companies linked to the vocations of the state, reinforcing the understanding that the companies that seek to innovate are those that have developed absorption capacity for this (Rapini, 2007).

There were a significant number of university partnerships in the programs and their movement from the development of basic research to applied research. We infer that these partnerships come from the paradigm shift in universities on the way to the posture of an entrepreneurial university (Etzkowitz, 2013), acting closer to society and using the triple helix interaction as a shorter and more practical means for this relationship, in a cohesive and well-structured manner (Etzkowitz, 2009).

Another result that draws attention is the constant proportion of programs that involved the triple helix by the total number of programs. It is reasonable to assume that this

TOTAL VOLUME OF INTERNATIONAL PARTNERSHIPS

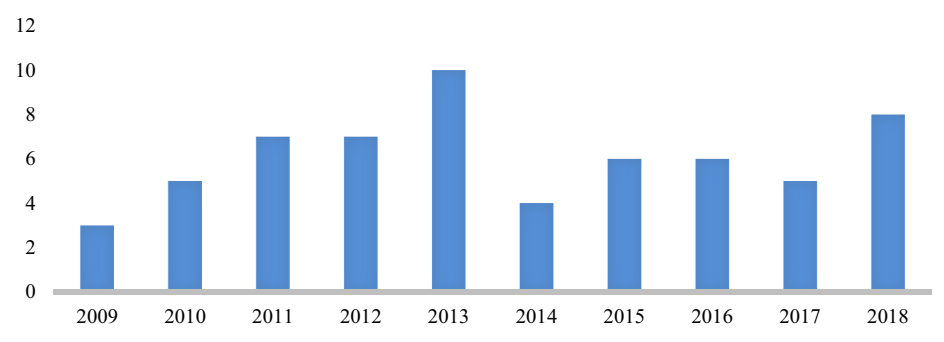

Source: Research data
Figure 7.

Countries participating in international partnerships in FAPEMIG programs from 2009 to 2018

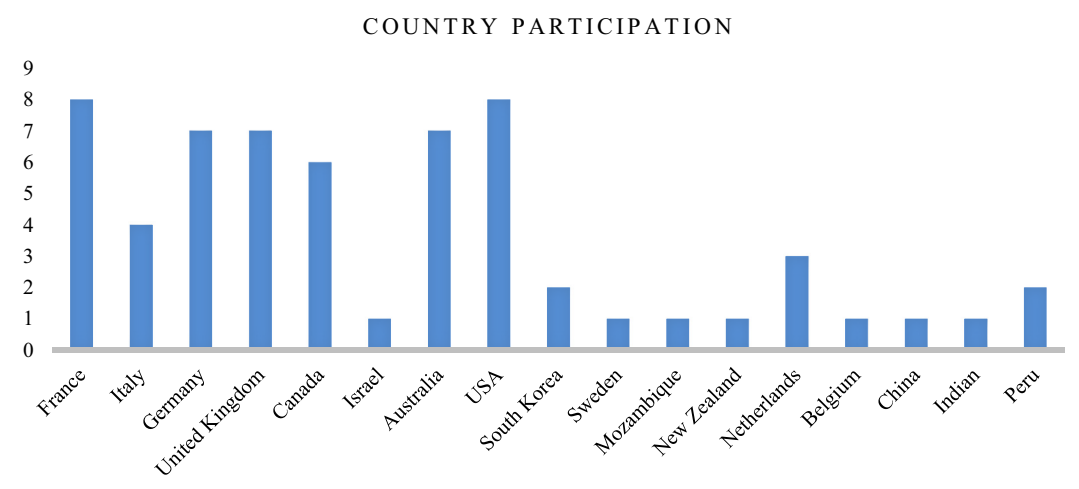

Source: Research data 
proportion had a tendency to increase, because of changes in state legislation, which encouraged the Minas Gerais Innovation Law of 2008, in a recent period, but this increase did not occur at Fapemig, at least not in the number of programs.

It is known that there are still many difficulties encountered in the triple helix model and much to be done to make this interaction more fluid in the country. The works of SegattoMendes and Sbragia (2002) and Audy (2006) highlight obstacles such as the length of the process, administrative philosophies of different institutions, degree of uncertainty of the projects, lack of communication between the parties, instability of public universities, lack of confidence in the capacity of human resources, excessive bureaucracy in universities and the view that the state should be the sole financier of activities. These are obstacles that demand long-term changes, and that could possibly be justifications for the lack of this expected increase.

It was not possible to measure whether the financial contribution made to these programs increased, because of the lack of clarity of the financial data in the reports, which sometimes appear and are sometimes not mentioned. These data also do not coincide with the Transparency Portal, where the values of the notices are published, which are large subdivisions of the programs. Thus, the reports should be more transparent, with greater consistency of information regarding financial data.

Another important point for the time frame used in the research, whose analyzed data goes from 2009 to 2018, is the current rupture of public management models at the state and federal levels. Situated, until then, more at the center and the left of the Brazilian political spectrum, in the recent election of 2018, both are on the right of it, allowing future studies to establish a comparison between them.

It is also suggested to replicate the study in FAPEs from other states, aiming to compare the dynamics and in other development institutions such as the $\mathrm{CNPq}$ and the Coordination for the Improvement of Higher Education Personnel. As well as updating this study after the finalization of current governments, it is possible to verify possible impacts of changes in the political scenario in the management of public resources in S\&T in Brazil. It is also recommended to reinforce the qualitative analyses, with interviews with key actors of this system to understand their view on the operation of the triple helix in the state.

Despite the limitations, this research brings theoretical contributions to the gap in literature on the triple helix, because it analyzes recent data on this interaction in Minas Gerais, where research and understanding on the subject is scarce.

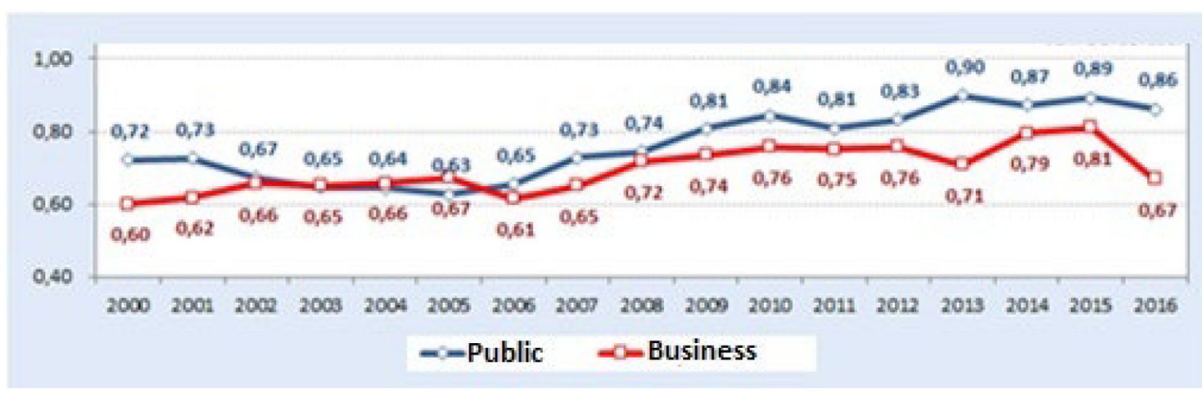

Source: Ministry of Science, Technology, Innovations and Communications (2018)

Analysis from Fapemig data

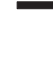


INMR

17,4

Possible practical contributions of this research are understood as the use of the analysis of this strategic interaction for the state by public managers as a decision-making tool. Once the importance of the role of space of consensus realized by Fapemig is evidenced, there is the possibility of intensifying the efforts so that the actions in this sense are expanded, as well as the still existing dependence on the promotion directed by it for this interaction to occur in the state, demanding actions of partnerships and attracting investments.

As for the articulation of the triple helix interaction and acting as a government agent, Fapemig could highlight in its reports for universities with greater involvement in its programs, so that they can serve as benchmarking for others who find it more difficult and seek to involve companies from emerging sectors in their programs to spread innovation in the state, and, if this is already done, seek to expose this more in their reports to encourage more companies in these sectors to take advantage of this type of interaction.

The objective of this work was to clarify the functioning of the triple helix interaction, through a case study of Fapemig's role as an inducer of this relationship in the state of Minas Gerais, between 2009 and 2018. To carry out this research, data were collected from all activity reports published by the institution in that period.

From this analysis, it was noticed that Fapemig acted effectively for the triple helix interactions to occur in the state. It showed itself to be a fundamental agent for innovation and the development of interactions between the state, universities and companies in Minas Gerais, through the creation of programs, offered in public notices, financing them and creating a space of consensus among the agents.

\section{References}

Albuquerque, E. D. M. (1999). National systems of innovation and Non-OECD countries: notes about a rudimentary and tentative typology. Brazilian Journal of Political Economy, 19(4), 76. Retrieved from http://www.rep.org.br/PDF/76-3.PDF

Almeida, M. (2004). Incubadoras, parques tecnológicos e inclusão social no Brasil., IX Congreso Internacional del CLAD sobre la Reforma del Estado y de la Administración Pública, Madrid, Espanha, Recuperado de https://cladista.clad.org/handle/123456789/3153

Alvim, S. D. J. G. (2019). O uso do modelo de tripla hélice nas ações do CNPq: o caso da chamada pública MCTI/CNPq-ISTPCANADA $n^{\circ}$ 19/2012. (trabalho de conclusão de curso). Escola Nacional de Administração Pública, Brasília, DF, Brasil. Retrieved from http://repositorio.enap.gov.br/ bitstream/1/3899/1/TCC-ENAP\%20Silmary\%20Alvim-15.03.2019.pdf

Amaral, M. G., \& Messias, N. R. (2018). Analise das comunicações cientificas sobre a abordagem e o movimento da triple helix. São Paulo, SP: Anais do XXI SEMEAD Seminários em Administração. Anais (online). Retrieved from http://login.semead.com.br/21semead/anais/resumo.php? cod_trabalho $=358$

Arantes, A. P., \& Serpa, C. V. (2012). O modelo da tríplice hélice como fator de desenvolvimento de Santa Rita do sapucai. XXII Seminário Nacional de Parques Tecnológicos e Incubadoras de Empresas. ANPROTEC. Retrieved from http://home.ufam.edu.br/hiramaral/04_SIAPE_FINAL_2016/ SIAPE_Biblioteca \%20Geral/00000_MeDSE_Mendeley_2015/MeDSE_TRIPLICE_HELICE/1\% 20ARTIGO \%20FINAL \%20_ANPROTEC.pdf

Audy, J. L. N. (2006). Entre a tradição e a renovação: Os desafios Da universidade empreendedora. In J. L. N. Audy, (Ed.) Inovação e empreendedorismo na universidade (Vol. 2, p. 44). Porto Alegre: EDIPUCRS.

Bardin, L. (2011). Análise de conteúdo (6a ed., p. 70). Lisboa: Edições.

Buesa, M., Heijs, J., Pellitero, M. M., \& Baumert, T. (2006). Regional systems of innovation and the knowledge production function: the Spanish case. Technovation, 26(4), 463-472, doi: https://doi. org/10.1016/j.technovation.2004.11.007. 
Carayannis, E. G., \& Rakhmatullin, R. (2014). The quadruple/quintuple innovation helixes and smart specialisation strategies for sustainable and inclusive growth in Europe and beyond. Journal of the Knowledge Economy, 5(2), 212-239, doi: https://doi.org/10.1007/s13132-014-0185-8.

Carvalho, F. M. A., \& Coronel, D. A. (2012). Políticas públicas, desenvolvimento regional e inovação em Minas Gerais. Qualitas Revista Eletrônica, 13(1). Retrieved from http://revista.uepb.edu.br/index. $\mathrm{php} /$ qualitas/article/viewFile/1408/787

Cingolani, L. (2013). The state of state capacity: a review of concepts, evidence and measures. Retrieved from https://www.merit.unu.edu/publications/working-papers/abstract/?id=5017

Cooke, P. (2005). Regionally a symmetric knowledge capabilities and open innovation: exploring 'globalisation 2' - a new model of industry organisation. Research Policy, 34(8), 1128-1149, doi: https://doi.org/10.1016/j.respol.2004.12.005.

Coutinho, E. C. F. (2018). Interações entre universidade, indústria e governo Para inovação no Brasil, sob a ótica teórica da tríplice hélice. Universidade Federal de Uberlândia, MG, Brasil. Retrieved from https://repositorio.ufu.br/handle/123456789/22401

Doloreux, D., \& Parto, S. (2005). Regional innovation systems: current discourse and unresolved issues. Technology in Society, 27(2), 133-153, doi: https://doi.org/10.1016/j.techsoc.2005.01.002.

Edquist, C. (2010). Systems of innovation perspectives and challenges. African Journal of Science, Technology, Innovation and Development, 2(3), 14-45, doi: https://oi.org/10.1093/oxfordhb/ 9780199286805.003.0007.

Etzkowitz, H. (2009). Hélice tríplice: universidade-indústria-governo inovação em ação, Edipucrs.

Etzkowitz, H. (2013). Anatomy of the entrepreneurial university. Social Science Information, 52(3), 486511, doi: https://doi.org/10.1177\%2F0539018413485832.

Etzkowitz, H., \& Zhou, C. (2017). The triple helix: University-industry-government innovation and entrepreneurship (2a ed.). London: Routledge, doi: https://doi.org/10.4324/9781315620183

Etzkowitz, H., Mello, J. M. C., \& Almeida, M. (2005). Towards 'meta-innovation' in Brazil: the evolution of the incubator and the emergence of a triple helix. Research Policy, 34(4), 411-424, doi: https:// doi.org/10.1016/j.respol.2005.01.011.

Fundação de Amparo à Pesquisa de Minas Gerais. (2019). Institucional. Retrieved from https://fapemig. $\mathrm{br} / \mathrm{pt} /$

Godoi, C., Bandeira-de-Melo, R., \& Silva, A. (2010). Pesquisa qualitativa em estudos organizacionais (2nd ed.). São Paulo: Saraiva.

Instituto Brasileiro de Geografia e Estatística. (2019). Pesquisa cidades - belo horizonte. Retrieved from https://cidades.ibge.gov.br/brasil/mg/panorama

Leydesdorff, L., \& Meyer, M. (2006). Triple helix indicators of knowledge-based innovation systems. Research Policy, Retrieved from http://hdl.handle.net/10150/105982

Leydesdorff, L., \& Etzkowitz, H. (1998). The triple helix as a model for innovation studies. Science and Public Policy, 25(3), 195-203, doi: https://doi.org/10.1093/spp/25.3.195.

Lopes, D. P. T., \& Barbosa, A. C. Q. (2008). Inovação: conceitos, metodologias e aplicabilidade. Articulando um construto à formulação de políticas públicas. Uma reflexão sobre a lei de inovação de Minas Gerais. Anais do XIII Seminário sobre a Economia Mineira, Belo Horizonte. Retrieved from https://core.ac.uk/download/pdf/6519751.pdf

Mazzucato, M. (2015). The entrepreneurial state: Debunking public vs. private sector myths (Vol. 1). Anthem Press.

Minayo, M. C. D. S. (1994). Pesquisa social: teoria, método e criatividade, Petrópolis: Vozes.

Moura, G. L. D. Silva, W. M. D., \& Fischmann, A. A. (2012). Competitividade e alianças: a inserção das universidades Brasileiras. FGV Repositório Digital. Retrieved from http:/hdl.handle.net/10438/19161

Mytelka, L. K. (2016). Innovation systems approaches in a time of transition. Innovation Systems: Towards Effective Strategies in Support of Small Holder Farmers, 24. 
INMR

17,4

Pereira, R. M., Marques, H. R., Garcia, M. O., \& Gava, R. (2015). Sistemas de inovação regionais: a estrutura científico-tecnológica de Minas Gerais, XVI Congresso Latino-Iberoamericano de Gestão da Tecnologia, Porto Alegre. Retrieved from www.researchgate.net/profile/ Rodrigo_Gava/publication/283150312_Sistemas_DeInovacao_Regionais_A_Estrutura_Cientifico_ Tecnologica_De_Minas_Gerais/links/577c051208ae213761cab7c0.pdf

Ranga, M., \& Etzkowitz, H. (2015). Triple helix systems. Entrepreneurship and Knowledge Exchange, 7 , 107.

Rapini, M. S. (2007). Interação universidade-empresa no Brasil: evidências do diretório dos grupos de pesquisa do CNPq. Estudos Econômicos (São Paulo)), 37(1), 211-233, doi: https://doi.org/10.1590/ S0101-41612007000100008.

Rizzi, D., Mazzioni, S., Poli, O., \& Moura, G. (2018). O modelo da hélice tríplice: produção intelectual em periódicos nacionais e internacionais. Revista Gestão Universitária na América Latina - GUAL, 11(2), 110-132, doi: https://doi.org/10.5007/1983-4535.2018v11n2p110.

Rodrigues, F. C. R., \& Gava, R. (2016). Capacidade de apoio à inovação dos institutos federais e das universidades federais no estado de Minas Gerais: um estudo comparativo. REAd. Revista Eletrônica de Administração (Porto Alegre)), 22(1), 26-51, doi: https://doi.org/10.1590/14132311.0282015.5445.

Salles, F. C., Rocha, E. M. P. D., Porto, I. V. D B., \& Vasconcelos, F. L. V. (2017). A armadilha da baixa complexidade em Minas Gerais: o desafio da sofisticação econômica em um estado exportador de commodities. Revista Brasileira De Inovação, 17(1), 33-62, doi: https://doi.org/10.20396/rbi. v17i1.8650857.

Segatto-Mendes, A. P., \& Sbragia, R. (2002). O processo de cooperação universidade-empresa em universidades brasileiras. Revista de Administração da Universidade de São Paulo, 37(4). Retrieved from www.researchgate.net/publication/311426283

Sobrinho, I. C., \& Gonçalves, E. (2011). Instrumentos de apoio financeiro Para parques tecnológicos: a experiência de Minas Gerais. Revista de Economia, 37(2), doi: https://doi.org/10.5380/re. v37i2.27239.

Sousa Júnior, C. C. (2014). O sistema regional de inovação do estado de Minas Gerais: uma análise a partir de suas organizações e interações. Retrieved from https://repositorio.ufmg.br/handle/1843/ BUOS-9NSK58

Todeva, E., Alshamsi, A. M., \& Solomon, A. (2019). The role of government/academia/industry in building Innovation-Based cities and nations. Triple Helix Best Practices, 1. Retrieved from https://research.stmarys.ac.uk/id/eprint/3800/

Wylinka \& Nesta. (2019). Understanding Brazil's innovation system. Retrieved from https://conteudo. wylinka.org.br/reportgipa

Yoon, J., Yang, J. S., \& Park, H. W. (2017). Quintuple helix structure of Sino-Korean research collaboration in science. Scientometrics, 113(1), 61-81, doi: https://doi.org/10.1007/s11192-0172476-x.

Corresponding author

Crystyane Ferreira Bernardino can be contacted at: crys.ferber@gmail.com

For instructions on how to order reprints of this article, please visit our website:

www.emeraldgrouppublishing.com/licensing/reprints.htm

Or contact us for further details: permissions@emeraldinsight.com 